N. M. Kononenko, V. V. Chikitkina, M. V. Sorokina, M. O. Ostapets

National University of Pharmacy

\title{
The study of hypolipidemic properties of Ginger extract on the model of type 2 diabetes induced by dexamethasone
}

Aim. To study experimentally the hypolipidemic properties of Ginger extract against the background of type 2 diabetes.

Materials and methods. The study of the hypolipidemic properties of Ginger extract was performed by the lipid metabolism indices on the model of type 2 diabetes induced by dexamethasone in rats aged 18 months.

Results and discussion. Experimental type 2 diabetes was accompanied with disorder of the lipid metabolism, it was confirmed by the increase of the content triacylglycerides, atherogenic apoB-lipoproteins with simultaneous reduction of high-density lipoproteins and increased release of free fatty acids from the adipose tissue. Under the effect of Ginger extract in the doses of 50 and $80 \mathrm{mg} / \mathrm{kg}$ the level of free fatty acids in the blood serum decreased by $38.4 \%$ and $38.9 \%$, probably due to correction of insulin resistance manifestations and preservation of the insulin control effect on lipolysis. The reliable inhibition of hypertriacylglycerolemia severity by Ginger extract in the dose of $80 \mathrm{mg} / \mathrm{kg}$ by $35.1 \%$ correlated with a decrease of apoB-LP production in the liver, and it indicated correction of diabetic dyslipidemia. At the same time, the level of the antiatherogenic fraction - high-density lipoproteins - significantly increased by 26.1 and $29.5 \%$ under the effect of the extract in the doses of 50 and $80 \mathrm{mg} / \mathrm{kg}$, respectively, compared to the values of animals of the control pathology. Ginger extract in the dose of $80 \mathrm{mg} / \mathrm{kg}$ showed a more expressive ability to normalize the lipid metabolism at the level of the reference drug - "Arphasetin" herbal medicinal product.

Conclusions. Introduction of Ginger extract for 14 days in the doses of 50 and $80 \mathrm{mg} / \mathrm{kg}$ on the model of type 2 diabetes induced by dexamethasone was accompanied with a reliable normalization of the lipid metabolism. The use of Ginger extract in the dose of $80 \mathrm{mg} / \mathrm{kg}$ is most pronounced at the level of the reference drug - "Arphasetin" herbal medicinal product, corrected the pathological changes in the lipid metabolism characteristic for type 2 diabetes. It allows making a conclusion concerning the feasibility of further studies of the extract exactly in this dose and the prospects of its use as an antiatherogenic drug in the complex treatment of type 2 diabetes.

Key words: Ginger extract; type 2 diabetes mellitus; dexamethasone; hypolipidemic action

\section{Н. М. Кононенко, В. В. Чікіткіна, М. В. Сорокіна, М. О. Остапець}

Дослідження гіполіпідемічних властивостей естракту імбиру на моделі цукрового діабету 2 типу, індукованого дексаметазоном

Мета - експериментальне дослідження гіполіпідемічних властивостей екстракту імбиру на тлі ЦД 2 типу.

Матеріали та методи. Дослідження гіполіпідемічних властивостей екстракту імбиру проводили за показниками ліпідного обміну на моделі ЦД 2 типу, індукованого дексаметазоном у щурів 18-місячного віку.

Результати та їх обговорення. Експериментальний ЦД 2 типу супроводжувався порушенням ліпідного обміну, що підтверджувалось зростанням триацилгліцеридів, вмісту атерогенних апоВ-ліпопротеїнів за умови одночасного зниження ліпопротеїнів високої щільності та посиленням вивільнення вільних жирних кислот з жирової тканини. Під впливом екстракту імбиру у дозах 50 та 80 мг/кг знижувався рівень вільних жирних кислот у сироватці крові на 38,4 \% та 38,9 \%, вірогідно, внаслідок корекції проявів інсулінорезистентності та збереження керуючого впливу інсуліну на ліполіз. Достовірне пригнічення вираженості гіпертриацилгліцеролемії екстрактом імбиру дозою 80 мг/кг на 35,1 \% корелювало зі зменшенням продукції апоВ-ЛП у печінці, що свідчило про корекцію діабетичної дисліпідемії. При цьому рівень антиатерогенної фракції - ліпопротеїнів високої щільності достовірно підвищувався на 26,1 та 29,5 \% під впливом екстракту у дозах 50 та 80 мг/кг відповідно порівняно з показниками тварин контрольної патології. Екстракт імбиру дозою 80 мг/кг виявив більш виразну здатність нормалізувати показники ліпідного обміну на рівні препарату порівняння збору «Арфазетин».

Висновки. Введення екстракту імбиру протягом 14-ти діб у дозах 50 та 80 мг/кг на моделі ЦД 2 типу, індукованого дексаметазоном, супроводжувалось достовірною нормалізацією ліпідного обміну. Застосування екстракту імбиру дозою 80 мг/кг найбільш виражено на рівні препарату порівняння збору «Арфразетин» корегувало патологічні зміни метаболізму ліпідів, характерні для ЦД 2 типу, що дозволяє зробити висновок про доцільність подальших досліджень екстракту саме у цій дозі та перспективність його застосування як антиатерогенного засобу у комплексному лікуванні ЦД 2 типу.

Ключові слова: екстракт імбиру; иукровий діабет 2 типу; дексаметазон; гіполіпідемічна дія 
Н. Н. Кононенко, В. В. Чикиткина, М. В. Сорокина, М. А. Остапец

\section{Исследование гиполипидемических свойств экстракта имбиря на модели сахарного диабета 2 типа, индуцированного дексаметазоном}

Цель - экспериментальное исследование гиполипидемических свойств экстракта имбиря на фоне СД 2 типа.

Материалы и методы. Исследование гиполипидемических свойств экстракта имбиря проводили по показателям липидного обмена на модели СД 2 типа, индуцированного дексаметазоном у крыс 18-месячного возраста.

Результаты и их обсуждение. Экспериментальный СД 2 типа сопровождался нарушением липидного обмена, что подтверждалось ростом триацилглицеридов, содержания атерогенных апоВ-липопротеинов при одновременном снижении липопротеинов высокой плотности и усилении высвобождения свободных жирных кислот из жировой ткани. Под влиянием экстракта имбиря в дозах 50 и 80 мг/кг снижался уровень свободных жирных кислот в сыворотке крови на 38,4 \% и 38,9 \%, вероятно, вследствие коррекции проявлений инсулинорезистентности и сохранения управляющего воздействия инсулина на липолиз. Достоверное подавление выраженности гипертриацилглицеролемии экстрактом имбиря в дозе 80 мг/кг на 35,1 \% коррелировало с уменьшением продукции апоВ-ЛП в печени, что свидетельствовало о коррекции диабетической дислипидемии. При этом уровень антиатерогенной фракции - липопротеинов высокой плотности достоверно повышался на 26,1 и 29,5 \% под влиянием экстракта в дозах 50 и 80 мг/кг соответственно по сравнению с показателями животных контрольной патологии. Экстракт имбиря в дозе 80 мг/кг проявил более выразительную способность нормализовать показатели липидного обмена на уровне препарата сравнения сбора «Арфазетин».

Выводы. Введение экстракта имбиря в течение 14-ти суток в дозах 50 и 80 мг/кг на модели СД 2 типа, индуцированного дексаметазоном, сопровождалось достоверной нормализацией липидного обмена. Применение экстракта имбиря в дозе 80 мг/кг, наиболее выраженное на уровне препарата сравнения сбора «Арфазетин», корректировало патологические изменения метаболизма липидов, характерные для СД 2 типа, что позволяет сделать вывод о целесообразности дальнейших исследований экстракта именно в этой дозе и перспективности его применения в качестве антиатерогенного средства в комплексном лечении СД 2 типа.

Ключевые слова: экстракт имбиря; сахарный диабет 2 типа; дексаметазон; гиполипидемическое действие

One of the global problems of modern medicine is diabetes mellitus (DM), namely, type 2 diabetes, which accounts for about $90 \%$ of all cases and has an epidemic in the world [1].

The primary link in the pathogenesis of type 2 diabetes and the metabolic syndrome (MS) as a pre-diabetes condition is primary insulin resistance, which results in significant changes in the carbohydrate and lipid metabolism, and increased risk of cardiovascular disease, progression of atherosclerosis and mortality in patients with type 2 diabetes mellitus.

Therefore, the main strategy of the modern therapy of type 2 diabetes is to prevent development of cardiovascular complications, including a strict control of glycemia, arterial pressure, as well as the antiplatelet and hypolipidemic therapy.

Nowadays, there is no conclusive evidence of the effectiveness of most oral antihyperglycemic drugs to reduce the risk of diabetic macroangiopathy; besides, a lot of them have unwanted side effects and reduced therapeutic activity in the long-term use, indicating the relevance of the search and expansion of the range of new antidiabetic drugs that would be characterized not only by high hypoglycemic properties, but also by the preventive action against cardiovascular complications [2].

Taking into account the leading role of activation in the lipid peroxidation processes (LDL) in the pathogenesis of type 2 diabetes and its complications it is expedient and promising to use medicinal plants and drugs on their basis with hypoglycemic and antioxidant properties in the complex therapy of the disease.

Medicinal plants are well combined with antidiabetic drugs increasing their therapeutic effect, improving the tissue sensitivity to insulin, activating reparative processes in $\beta$-cells of the pancreas, in the absence of toxicity and the risk of adverse reactions in the long-term use.

Nowadays, more than 150 types of medicinal plants used in non-traditional medicine in many countries of the world for the treatment of diabetes are known, but the list of officinal antidiabetic drugs on their basis is insufficient, and in Ukraine it is limited only by herbal medicinal products "Arphasetin" and "Sadiphytum" $[3,4]$, it has served as a reasoning in development and the pharmacological study of ginger extract.

Ginger (Zingiber) due to the rich chemical composition of its roots has a wide range of pharmacological properties. For today its antioxidant, antimicrobial, antiinflammatory, neuroprotective, anti-ulcer and antitumor effects have been proven [5-7]. The studies of the last years also indicated hypoglycemic and hypolipidemic properties of ginger, and it allowed to assume the effectiveness of ginger extract in the metabolic syndrome (MS) and type 2 diabetes $[8,9]$.

The aim of this work was study experimentally the hypolipidemic properties of Ginger extract against the background of type 2 diabetes induced by dexamethasone.

\section{Materials and methods}

The experiments were performed on 40 18-month nonlinear female rats kept under standard vivarium conditions of the Central Research Laboratory of the National University of Pharmacy. All manipulations with animals were conducted in accordance with the requirements of the "European Convention for the Protection of Vertebrate Animals Used for Experimental and Scientific Purposes" (Strasbourg, 1986). 

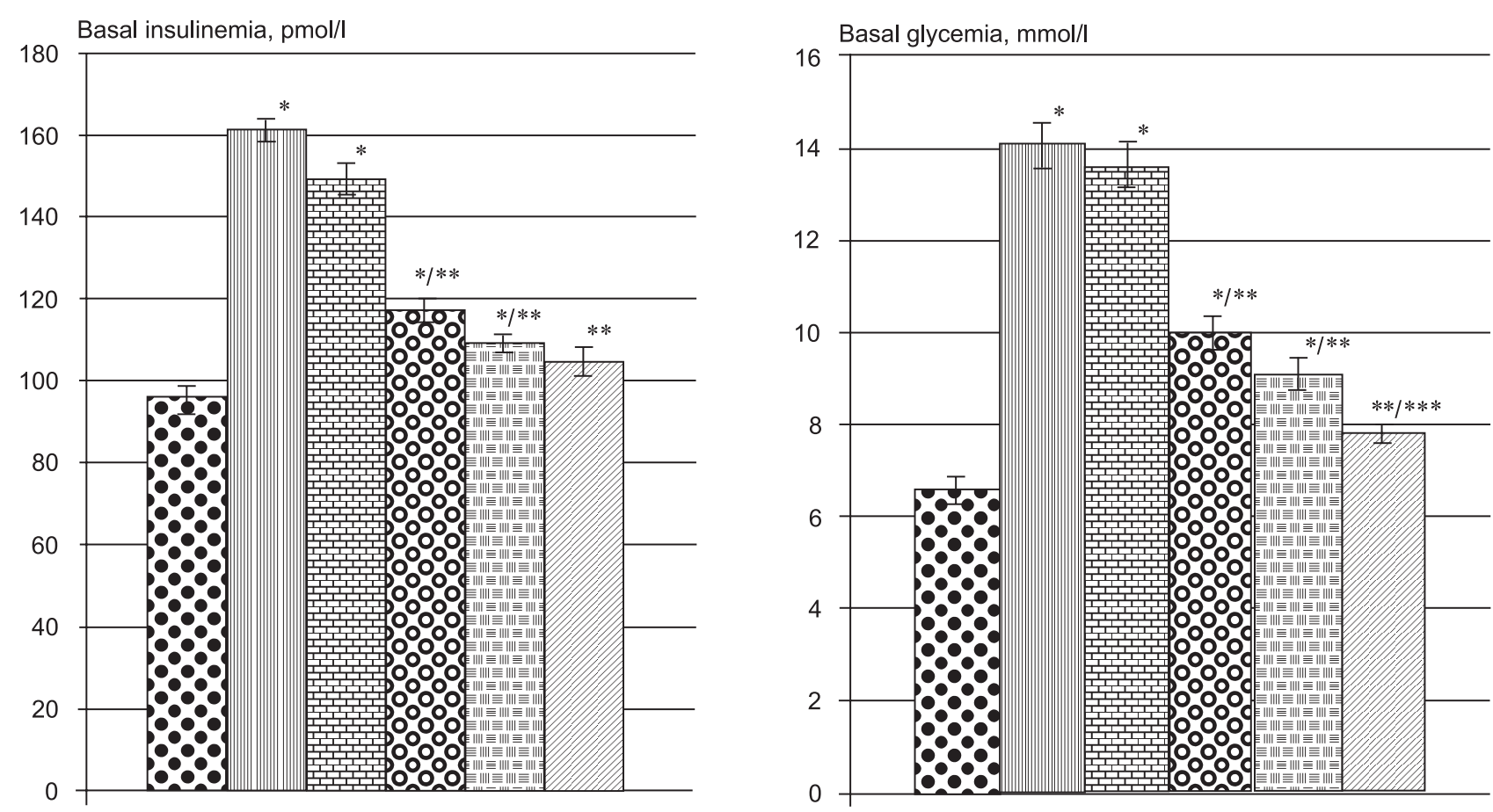

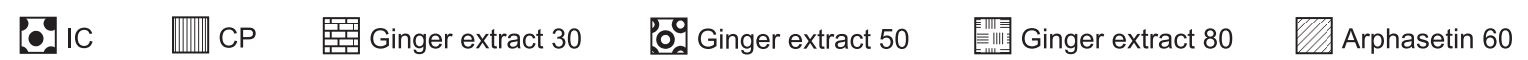

Fig. The effect of ginger extract on indicators of the carbohydrate metabolism in the blood serum of rats in conditions of type 2 diabetes induced by dexamethasone, $\mathrm{M} \pm \mathrm{m}$. The number of animals in each group $=7$.

Notes: ${ }^{*}$ - the differences are statistically significant compared to the values of the IC group $(p \leq 0.05) ;{ }^{* *}$ - the differences are statistically significant compared to the values of the CP group $(p \leq 0.05) ;{ }^{* * *}$ - the differences are statistically significant compared to the values of the group treated with Ginger extract $(p \leq 0.05)$.

As a reference drug "Arphasetin" herbal medicinal product with the proven hypoglycemic activity was used; it was registered as a drug and authorized for medical use in Ukraine as part of integrated therapy of type 2 diabetes.

Type 2 diabetes was reproduced by subcutaneous introduction of synthetic glucocorticoid dexamethasone (Dexamethasone-KRKA, produced by KRKA, Slovenia) in the dose of $0.125 \mathrm{mg} / \mathrm{kg}$ for 13 days [10].

The substances studied were injected during the simulation period once per day 1 hour before introduction of dexamethasone.

Animals were divided into the following groups: intact control (IC); control pathology (CP) - received dexamethasone; 4 experimental groups: 1-3 groups - on the background of dexamethasone received an intragastric aqueous solution of ginger extract in the doses of 30 , 50 and $80 \mathrm{mg} / \mathrm{kg}$, respectively; group 4 - on the background of dexamethasone received an intragastric infusion of the reference drug "Arphasetin" in the dose of $16 \mathrm{ml} / \mathrm{kg}$.

On day 14 all rats were removed from the experiment by decapitation under etheric anesthesia, in their blood serum the biochemical parameters of the lipid profile were determined.

The level of triacylglycerols (TAG) in the blood serum and in the liver homogenates was determined using the standard kit of reagents "KONE" (Finland) by the glycerol oxidation method.

The content of high density lipoprotein (HDL) and apo-B-containing lipoproteins (the total amount of low density lipoprotein (LDL) and very low density lipoproteins (VLDL) - apoB-LP) was determined in the blood serum using the turbidimetric method [11].

Determination of the concentration of free fatty acids (FFA) in the blood serum was carried out using a kit of reagents of "Felicith Diagnostics" (Ukraine) by the reaction with diethyl dithiocarbamate.

The statistical processing of the results was performed on a personal computer using Excel packages and Statistica 6.0 for Windows. For determination of probable differences between the experimental groups the NewmanKeels and the Mana-Whitney tests were used. Differences were considered to be statistically significant at $p<0.05$.

\section{Results and discussion}

As a result of dexamethasone introduction in animals of the CP group a significant increase in basal glycemia by 2.13 times and basal insulinemia by 1.68 times was observed compared to the IC group, it allowed to determine the reproduction of type 2 diabetes (Fig.).

Development of DM 2 was accompanied with the lipid metabolism disorders, which was confirmed by a significant increase of the TAG content in the blood serum by 1.98 times compared to the IC group (Table). 
The effect of Ginger extract on indicators of the lipid metabolism in the blood serum in rats on the model of 2 type of diabetes mellitus induced by dexamethasone, $M \pm m(n=7)$

\begin{tabular}{|c|c|c|c|c|}
\hline \multirow{2}{*}{ The group of animals } & \multicolumn{4}{|c|}{ Indicators } \\
\hline & $\mathrm{HDL}, \mathrm{mmol} / \mathrm{l}$ & $\mathrm{VHDL}, \mathrm{mg} / \mathrm{ml}$ & apoB-LP, mg/ml & TAG, $\mathrm{mmol} / \mathrm{l}$ \\
\hline IC & $0.678 \pm 0.009$ & $1.23 \pm 0.03$ & $5.16 \pm 0.02$ & $0.827 \pm 0.073$ \\
\hline$C P$ & $1.956 \pm 0.013^{*}$ & $0.88 \pm 0.06$ & $7.22 \pm 0.07^{*}$ & $1.643 \pm 0.115^{*}$ \\
\hline Ginger extract, $30 \mathrm{mg} / \mathrm{kg}$ & $1.765 \pm 0.011^{*}$ & $0.94 \pm 0.04^{*}$ & $6.93 \pm 0.08^{*}$ & $1.475 \pm 0.088^{*}$ \\
\hline Ginger extract, 50 mg/kg & $1.202 \pm 0.018^{*} / * *$ & $1.11 \pm 0.05^{*} / * *$ & $6.02 \pm 0.03^{*} / * *$ & $1.114 \pm 0.074^{*} / * *$ \\
\hline Ginger extract, $80 \mathrm{mg} / \mathrm{kg}$ & $1.195 \pm 0.011^{*} / * *$ & $1.14 \pm 0.02 * / * *$ & $5.95 \pm 0.04^{* *}$ & $1.067 \pm 0.043^{*} / * *$ \\
\hline "Arphasetin", $60 \mathrm{ml} / \mathrm{kg}$ & $1.192 \pm 0.009 * / * *$ & $1.10 \pm 0.04^{*} / * *$ & $5.97 \pm 0.03^{* *}$ & $1.098 \pm 0.021 * / * *$ \\
\hline
\end{tabular}

Notes: * the differences are statistically significant compared to the values of the IC group ( $p \leq 0.05)$; ${ }^{* *}$ the differences are statistically significant compared to the values of the CP group ( $\mathrm{p} \leq 0.05)$.

It is known that formation of hypertriacylglycerolemia is considered one of the key factors in development of proatherogenic changes characteristic of type 2 diabetes, resulting in formation of vascular complications [12].

It was confirmed by imbalance of lipoprotein fractions - by $39.9 \%$ compared to the IC group, the content of atherogenic apo-lipoproteins significantly increased, while simultaneously the antiatherogenic fraction - HDL reduced by $28.5 \%$ (Table).

In view of the fact that insulin resistance was formed in rats of the CP group there was a decrease in the inhibitory effect of insulin on lipolysis, resulting in the increased release of HDL from the adipose tissue; it was confirmed by an increase in their serum content by 2.88 times compared to the IC group (Table).

It is known that FFA due to its lipoprotective properties can aggravate the course of type 2 diabetes affecting the pancreas. In our experiment, obviously, an excess of FFA was delivered to the liver where they were involved in the release of TAG, and it was consistent with the findings regarding expressive hypertriacylglycerolemia. At the same time, it was logical to increase the content of atherogenic fractions of lipoproteins, in particular $\mathrm{LPDH}$, the main transport form of endogenous lipids, and transformed into LDL in the bloodstream.

The use of Ginger extract in the doses of 50 and $80 \mathrm{mg} / \mathrm{kg}$ resulted in the decrease of the level of FFA in the blood by $38.4 \%$ and $38.9 \%$, respectively, and it was accompanied with normalization of a number of metabolic links, in particular the reduction of the lipotoxic effect of high FFA correlated with partial restoration of tyrosine kinase activity of the insulin receptor, which led to a decrease in the severity of manifestations of insulin resistance (Table, Fig.).

Introduction of Ginger extract in the dose of $50 \mathrm{mg} / \mathrm{kg}$ reduced the manifestations of hypertriacylglycerolemia verified by a significant decrease in the serum TAG level by $32.2 \%$ compared to the $\mathrm{CP}$ group (Tab.). At the same time, under the effect of Ginger extract in the dose of $80 \mathrm{mg} / \mathrm{kg}$, a more pronounced inhibition of hypertriacylglycerolemia was observed by $35.1 \%$ compared to the values in the CP group (Tab.). It was probably due to a decrease in the FFA content, which under such conditions was less active and involved in the re-synthesis of TAG in the liver.

Reduction of hypertriacylglycerolemia manifestations in conditions of introduction of Ginger extract correlated with normalization of the ratio of lipoprotein fractions. There was a probable decrease in the content of apoB-LP under the effect of Ginger extract in the doses of 50 and $80 \mathrm{mg} / \mathrm{kg}$ by 16.7 and $17.6 \%$, respectively. At the same time, the level of the antiatherogenic fraction - high-density lipoproteins - significantly increased by 26.1 and $29.5 \%$ under the effect of the extract in the doses of 50 and $80 \mathrm{mg} / \mathrm{kg}$, respectively, compared to the values of animals of the control pathology (Table).

In addition, it can be predicted that the expressive hypolipidemic effect of Ginger extract is related to the antioxidant properties of Ginger since it is known that the activation of free radical processes plays one of the leading roles in atherogenesis due to the oxidative damage to lipoproteins.

Introduction of the reference drug "Arphasetin" was also accompanied with normalization of the lipid metabolism; it was confirmed by a significant decrease in FFA by $39.1 \%$ and TAG by $33.2 \%$ compared to the CP group. The content of atherogenic apoB-LP under the effect of "Arphasetin" decreased significantly by $17.4 \%$, while the HDL content increased by $25 \%$ compared to the animals of the CP group. The results obtained were compared to the data on the dynamics of the similar indicators under the effect of Ginger extract in the dose of $80 \mathrm{mg} / \mathrm{kg}$. Taking into account that "Arphasetin" herbal medicinal product is recommended for use as a part of the complex therapy of type 2 diabetes the relevant data obtained indicate the prospect of further study of Ginger extract as an antiatherogenic agent.

Introduction of Ginger extract in the dose of $30 \mathrm{mg} / \mathrm{kg}$ showed no significant effect on any of the parameters studied; it was confirmed by the absence of significant changes in the $\mathrm{CP}$ group although there was a downward trend. This is probably due to the fact that the dose of $30 \mathrm{mg} / \mathrm{kg}$ is not sufficient for the therapeutic effect of the extract studied. 
Thus, intragastric administration of Ginger extract in the dose of 50 and $80 \mathrm{mg} / \mathrm{kg}$ on the model of DMD type 2 in rats for 14 days was accompanied with a significant normalization of the lipid metabolism confirmed by the positive dynamics of the corresponding indices. It should be noted that the use of Ginger extract in the dose of $80 \mathrm{mg} / \mathrm{kg}$ was the most pronounced at the level of the reference drug - "Arphasetin" herbal medicinal product, corrected pathological changes in the lipid metabolism characteristic of type 2 diabetes. It suggests the feasibility of further studies of the extract exactly in this dose and the prospects of its use as an antidiabetic drug.

\section{CONCLUSIONS}

1. A daily subcutaneous introduction of dexamethasone in the dose of $0.125 \mathrm{mg} / \mathrm{kg}$ for 13 days led to development of insulin resistance and dyslipidemia characteristic of type 2 diabetes.
2. Under the effect of Ginger extract in the doses of 50 and $80 \mathrm{mg} / \mathrm{kg}$ the level of free fatty acids in the blood serum decreased, probably due to correction of insulin resistance manifestations and preservation of the insulin control effect on lipolysis. A significant inhibition of hypertriacylglycerolemia severity correlated with a decrease of apoB-LP production in the liver, and it indicated correction of diabetic dyslipidemia. Ginger extract in the dose of $80 \mathrm{mg} / \mathrm{kg}$ showed a more expressive ability to normalize the lipid metabolism at the level of the reference drug - "Arphasetin" herbal medicinal product.

3 . The results obtained substantiate the further pharmacological study of Ginger extract in the dose of $80 \mathrm{mg} / \mathrm{kg}$ as a promising antiatherogenic drug in the complex treatment of type 2 diabetes.

Conflict of Interests: authors have no conflict of interests to declare.

\section{REFERENCES}

1. Cheng, D. Prevalence, predisposition and prevention of type II diabetes / D. Cheng // Nutrition and Metabolism. - London, 2005. Vol. 2. -29 p.

2. Oral hypoglycemic drugs : Pathophysiological basis of their mechanism of action / B. Lorenzati, C. Zucco, S. Miglietta et al. // Pharmaceuticals. - 2010. - Vol. 3, Issue 9. - P. 3005-3020. doi: 10.3390/ph3093005

3. Квасова, Т. М. Исследование гипогликемических свойств и химического состава нового водорастворимого экстракта сбора арфазетин сухого : дис. ... канд. биол. наук : 14.03.06 / Т. М. Квасова. - Тверь, 2012. - 146 с.

4. Чекман, І. С. Комбінована фармакотерапія цукрового діабету 2-го типу / І. С. Чекман, В. В. Бондур, О. В. Клименко // Рациональная фармакотерапия. - 2016. - № 2 (39). - С. 25-31.

5. Karuppiah, P. Antibacterial effect of Allium sativum cloves and Zingiber officinale rhizomes against multiple-drug resistant clinical pathogens / P. Karuppiah, S. Rajaram // Asian Pacific J. of Tropical Biomed. - 2012. - Vol. 2, Issue 8. - P. 597-601. doi: 10.1016/ s2221-1691(12)60104-x

6. Anti-inflammatory effect of the essential oils of Ginger (Zingiber officinale Roscoe) in experimental rheumatoid arthritis / J. L. Funk, J. B. Frye, J. N. Oyarzo et al. // PharmaNutrition. - 2016. - Vol. 4, Issue 3. - P. 123-131. doi: 10.1016/j.phanu.2016.02.004

7. Proteasome inhibition mediates $\mathrm{p} 53$ reactivation and anti-cancer activity of 6-gingerol in cervical cancer cells / N. Rastogi, S. Duggal, S. K. Singh et al. // Oncotarget. - 2015. - Vol. 6, Issue 41. - P. 43310-43325. doi: 10.18632/oncotarget.6383

8. Preventative effect of Zingiber officinale on insulin resistance in a high-fat high-carbohydrate diet-fed rat model and its mechanism of action / Y. Li, V. H. Tran, B. P. Kota et al. // Basic and Clinical Pharmacol. and Toxicol. - 2014. - Vol. 115, Issue 2. - P. $209-215$. doi: $10.1111 /$ bcpt.12196

9. Redox properties of ginger extracts: Perspectives of use of Zingiber officinale Rosc. as antidiabetic agent / L. Račková, M. Cupáková, A. Tažký et al. // Interdisciplinary Toxicol. - 2013. - Vol. 6, Issue 1. - P. 26-33. doi: 10.2478/intox-2013-0005

10. Доклінічні дослідження лікарських засобів : метод. рек. / за ред. член-кор. НАМН України О. В. Стефанова. - К. : Авіценна, 2001. $-528 \mathrm{c}$.

11. Климов, А. Н. Турбидиметрический метод определения $\beta$-липопротеидов и хиломикронов в сыворотке крови и тканях / А. Н. Климов, Т. Н. Ловягина, Э. Б. Баньковская // Лабораторное дело. - 1966. - Т. 5. - С. 276-279.

12. Wakil, S. J. Fatty acid metabolism : target for metabolic syndrome / S. J. Wakil, L. A. Abu-Elheiga // J. of Lipid Res. - 2009. Vol. 50. - P. S138-S143. doi: 10.1194/jlr.r800079-jlr200

\section{REFERENCES}

1. Cheng, D. (2005). Prevalence, predisposition and prevention of type II diabetes. Nutrition and metabolism, 2. London, 29.

2. Lorenzati, B., Zucco, C., Miglietta, S., Lamberti, F., Bruno, G. (2010). Oral Hypoglycemic Drugs: Pathophysiological Basis of Their Mechanism of ActionOral Hypoglycemic Drugs: Pathophysiological Basis of Their Mechanism of Action. Pharmaceuticals, 3 (9), 3005-3020. doi: 10.3390/ph3093005

3. Kvasova, T. M. (2012). Issledovanie gipoglikemicheskikh svoistv i khimicheskogo sostava novogo vodorastvorimogo ekstrakta sbora arfazetin sukhogo. Tver, 146.

4. Chekman, I. S., Bondur, V. V., Klimenko, O. V. (2016). Ratcionalnaia farmakoterapiia, 2 (39), 25-31.

5. Karuppiah, P., Rajaram, S. (2012). Antibacterial effect of Allium sativum cloves and Zingiber officinale rhizomes against multiple-drug resistant clinical pathogens. Asian Pacific Journal of Tropical Biomedicine, 2 (8), 597-601. doi: 10.1016/s2221-1691(12)60104-x

6. Funk, J. L., Frye, J. B., Oyarzo, J. N., Chen, J., Zhang, H., Timmermann, B. N. (2016). Anti-inflammatory effects of the essential oils of ginger (Zingiber officinale Roscoe) in experimental rheumatoid arthritis. PharmaNutrition, 4 (3), 123-131. doi: 10.1016/j.phanu.2016.02.004

7. Rastogi, N., Duggal, S., Singh, S. K., Porwal, K., Srivastava, V. K., Maurya, R., Mishra, D. P. (2015). Proteasome inhibition mediates p53 reactivation and anti-cancer activity of 6-Gingerol in cervical cancer cells. Oncotarget, 6 (41), 43310-43325. doi: 10.18632/oncotarget.6383 
8. Li, Y., Tran, V. H., Kota, B. P., Nammi, S., Duke, C. C., Roufogalis, B. D. (2014). Preventative Effect of Zingiber officinaleon Insulin Resistance in a High-Fat High-Carbohydrate Diet-Fed Rat Model and its Mechanism of Action. Basic \& Clinical Pharmacology \& Toxicology, 115 (2), 209-215. doi: 10.1111/bcpt.12196

9. Račková, L., Cupáková, M., Ťažký, A., Mičová, J., Kolek, E., Koštálová, D. (2013). Redox properties of ginger extracts: Perspectives of use of Zingiber officinale Rosc. as antidiabetic agent. Interdisciplinary Toxicology, 6 (1). doi: 10.2478/intox-2013-0005

10. Stefanov, O. V. (2001). Doklinichni doslidzhennia likarskykh zasobiv. Kyiv: Avitsena, 528.

11. Klimov, A. N., Loviagina, T. N., Bankovskaia, E. B. (1966). Laboratornoe delo, 5, 276-279.

12. Wakil, S. J., Abu-Elheiga, L. A. (2008). Fatty acid metabolism: target for metabolic syndrome. Journal of Lipid Research, 50 (Supplement), S138-S143. doi: 10.1194/jlr.r800079-jlr200

\section{Information about authors:}

Kononenko N., Doctor of Medicine (Dr. habil.), professor, head of the Department of Pathological Physiology, National University of Pharmacy.

E-mail: kononenkonn76@gmail.com

Chikitkina V., Candidate of Biology (PhD), associate professor of the Department of Pathological Physiology, National University of Pharmacy.

E-mail: valentina.chikitkina@gmail.com

Sorokina M., postgraduate student of the Department of Pathological Physiology, National University of Pharmacy

Ostapets M., Candidate of Medicine (PhD), teaching assistant of the Department of Pathological Physiology, National University of Pharmacy.

E-mail: marina.ostapets.22@gmail.com

Відомості про авторів:

Кононенко Н. М., д-р мед. наук, професор, завідувач кафедри патологічної фізіології, Національний фармацевтичний університет.

E-mail: kononenkonn76@gmail.com

Чікіткіна В. В., канд. біол. наук, доцент кафедри патологічної фізіологіï, Національний фармацевтичний університет. E-mail: valentina.chikitkina@gmail.com Сорокіна М. В., аспірант кафедри патологічної фізіології, Національний фармацевтичний університет

Остапець М. О., канд. мед. наук, асистент кафедри патологічної фізіології, Національний фармацевтичний університет. E-mail: таrina.ostapets.22@gmail.com Сведения об авторах:

Кононенко Н. Н., д-р мед. наук, профессор, заведующая кафедрой патологической физиологии, Национальный фармацевтический университет.

E-mail: kononenkonn76@gmail.com

Чикиткина В. В., канд. биол. наук, доцент кафедры патологической физиологии, Национальный фармацевтический университет.

E-mail: valentina.chikitkina@gmail.com

Сорокина М. В., аспирант кафедры патологической физиологии, Национальный фармацевтический университет

Остапец М. А., канд. мед. наук, ассистент кафедры патологической физиологии, Национальный фармацевтический университет.

E-mail: marina.ostapets.22@gmail.com 